\title{
The Common European Sales Law proposal - European private law at the crossroads?
}

\author{
by Maren Heidemann
}

$\mathrm{T}$ This article discusses arguments in favour and against the legal basis of the Proposal for a Regulation of the European Parliament (EP) and the Council on a Common European Sales Law (CESL), published as COM (2011) 635 final of 11 October 2011. It considers the international private law as well as some individual substantive rules of both the Regulation and the actual sales law. Suggestions are made how to adjust and complement this instrument in order to achieve what the EU legislator is setting out to do, and indeed what the legal and trading community, including consumers, need.

Central problems with the proposal are found to be the intended exclusive role of CESL in relation to existing transnational rules of international commercial contracts and the weakly identified reasons for there being separate regimes for consumers and merchants in the first place. Both consumer and commercial contracts have specific characteristics and requirements which need legislative attention within the EU and beyond but which have not yet been carved out sufficiently by legal doctrine. Further research is therefore needed into the contents of typical consumer and merchant contracts, both formal and substantive. A consolidated and possibly separate and mandatory consumer law for the Common Market could then be tailored in a more integrated and convincing way.

\section{UNIQUE AND UNPRECEDENTED NEW LEGISLATION}

Looking at all the law that the European Union has passed which impacts on private law one can say that this is the first piece of substantive contract law, especially when using continental terminology. Generally, Directives and Regulations have to be regarded as public law. They are secondary laws passed by a legislative body on a supranational level, often addressed to other public bodies for implementation. Procedural law (in the case of, say, the Brussels I Regulation - Council Regulation (EC) No 44/2001) is also regarded as public law.

The outward appearance of this new legal instrument also provides a novelty among the range of EU legislative acts. The proposal comprises the following components:
- The Explanatory Memorandum consisting of five sections entitled Context of the proposal - Results of Consultations with the interested parties and impact assessments; Legal Elements of the Proposal; Budgetary implication; Additional Information. The Regulation (the so called chapeau) - 16 articles, preceded by 37 recitals of a preamble.

- Annex I (the Common European Sales Law itself) - 8 'Parts' divided into 18 Chapters covering 186 Articles altogether.

- Appendices (withdrawal notice and form).

- Annex II - Standard Information Notice.

\section{LEGAL BASIS}

The creators emphasise in the Explanatory Memorandum that the proposal is based on Article 114 TFEU. There had been much debate whether it ought to have been based on Art. 352 TFEU (see p 8, bottom line of the proposal (s 3 of the Explanatory memorandum)). This would have required Parliamentary or even nationwide procedure in many Member States.

Four opposing reasoned opinions under Article 6 of Protocol 2 to the TFEU (the "Lisbon Treaty") were received within the two month deadline (12 December 2011) by the Parliaments of Austria, Belgium, Germany and the UK, all complaining about breach of the subsidiarity principle (as that is the only ground for those opposing votes to be based on). The necessary number of votes to stop the process was not received, and therefore the chances of this proposal being rejected are very small given that the European Parliament (EP) already committed itself to supporting the proposal in June 2011 (see press release by the European Commission about the vote of 8 June 2011: "European Commission welcomes Parliament's support for an optional Europe-wide contract law", accessible at http://europa.eu/rapid/pressReleasesAction.do? reference $=\mathrm{IP} / 11 / 683$ \&format $=$ HTML\&aged $=0$ \&language $=$ EN\&guiLanguage $=\mathrm{en}[3$ April 2012]. The EP thereby accepted the equally unprecedented situation that a proposal was voted for and consulted about without the actual text being available for consideration. (The European 
Commission, Green Paper from the Commission on policy options for progress towards a European Contract Law for Consumers and Businesses, COM(2010)348final (2010) received 320 responses until 31 January 2011 with many of them commenting that it was difficult to comment on something that is yet unknown). Commentators had to argue blindly about this proposal while the text was drafted in secrecy by the expert group and the stakeholder group. Now that the text and full shape and content of the proposal are published, the consultation period is closed and comments no longer officially invited. Commentators can therefore only file tentative remarks to be considered in the general legislative process including final drafting.

\section{(i) Critique based on the subsidiarity argument}

Looking at the press release and supporting research (eg "Justice Newsroom: Common European Sales Law to boost trade and expand consumer choice" http://ec.europa.eu justice/newsroom/news/20111011_en.htm [9 April 2012], p 6).one cannot help noting a certain campaign style, even slightly pompous language, aiming to fight the cause for the Common European Sales Law. The large figures for turnover increases in the internal market and opinion figures in support of a common contract law are met by yet more figures gathered by consumer representation groups, such as Which? and Consumer Focus in the UK. These have been evaluated in the Reasoned Opinion issued by the UK House of Commons on 8 December 2011 (see eg points 19 and 20 of the 'Reasoned Opinion of the House of Commons. Submitted to the Presidents of the European Parliament, the Council and the Commission, pursuant to Article 6 of Protocol (No 2) on the Application of the Principles of Subsidiarity and Proportionality.' accessible as COD/2011/0284 at http://www.ipex.eu/IPEXLWEB/scrutiny/COD20110284/ukcom.do [3 April 2012]).

Some sections are suggesting opposite findings to those of the Commission by Which? and Consumer Focus where traders say they are not deterred from trade within the European market place by the existence of different laws. In addition, No 21 of the Opinion confirms research carried out by Dutch researchers showing that consumer rights are not a problem but enforcement is ( $\mathrm{M}$ de Hoon and $\mathrm{V}$ Mak, "Consumer Empowerment Strategies - A Rights-Oriented Approach Versus a Needs-Oriented Approach”, ZEuP (2011) 518). This point was also maintained in the Reasoned Opinion filed by the German Bundestag (December 2011).

The Bundestag points to the law and ECJ decision Case C-436/03 EP v Council [2006] ECR I-3733 regarding the new co-operative form of company, societas europea (BTDrucksache 17/8000, pages 5-6, accessible at http://dipbt.bundestag.de/dip21/btd/17/080/1708000.pdf [3 April 2012].):

"In those circumstances, the contested regulation, which leaves unchanged the different national laws already in existence, cannot be regarded as aiming to approximate the laws of the
Member States applicable to cooperative societies, but has as its purpose the creation of a new form of cooperative society in addition to the national forms" (para 44).

In addition, the Bundestag thinks that not even Article 352 TFEU, which provides a kind of gap-filling enabling rule, would be the correct legal basis due to a lack of harmonisation and even uniformisation achieved by the Regulation (it seems that the wording of Recital 9 of the Preamble did not convince). The Bundestag was supported by expert witnesses in its hearing who all agreed that this reasoning follows from a reverse conclusion drawn from the scope and purpose of Article 118 TFEU which enables the Union to create separate - as opposed to approximating - legal instruments only in the area of intellectual property rights.

The Bundestag also concludes that as the CESL cannot achieve what it sets out to do in terms of providing one comprehensive contract law EU-wide (see preamble recital 27 and see below), it cannot be in accordance with the principle of proportionality (BT Drucksache 17/8000, p 7).

While it is understandable that the question of legal basis was debated in such depth given that this is the very argument the reasoned opinion can be based on, it is somewhat disappointing to see the whole-hearted rejection that this new proposal received by the four national Parliaments that filed reasoned opinions. There are a number of reasons that lend support to the creation of a Common European Sales Law. Whether or not this should be passed in its present form, though, is a different matter. In the following, I will discuss issues of formal and substantive nature and suggest ways forward.

\section{(ii) Formal reasons in support of CESL}

The European Union legislature is bound to give quantitative and qualitative reasons in support of any proposal based on Article 114 TFEU observing the subsidiarity and proportionality principle in particular. Formally, this obligation has clearly been discharged by the conduct of research into the need and acceptance prospects of an optional common uniform contract law across Europe. Figures quantify the benefit for the internal market with reasonable credibility. The fact that figures can be disputed does not in itself discredit the project, as it is the nature of such research that it can be disproved. In this respect the political will underlying such a project can be sufficiently justified by the data presented.

An element of doubt arises from the fact that 36 per cent of traders express a difficulty arising from different contract laws, which means after all that 64 per cent do not see any problems in this area. Whether such a question ought to be determined by majority decision or polling, however, and whether this would count as one, cannot on the face of it be taken from the relevant EU legislation. Therefore the data can be said to emit mixed messages, but should not be necessarily disqualified for this reason. 
The proposal has not received the required number of rejective opinions and has therefore a good chance of being passed. It might open itself up to subsequent court proceedings, though, if the well founded arguments alleging a breach of Article 114 TFEU are ignored.

\section{(iii) Substantive reasons in support of CESL and the way forward}

From a legal viewpoint and in a substantive sense, the argument in favour of creating any uniform European contract law - optional, mandatory, comprehensive or fragmented - lies in the nature of the problem to be solved, and in the nature of the underlying task at hand.

This task relates to the specific situation which has been promoted by the European Union ever since its foundation, that is cross border trade. Cross border trade involves contracts to be concluded and performed across borders and these can therefore be called transnational. The expressions "international contract" and "transnational contract" are interchangeable according to established use of language, but in the area of private law and private actors the latter expression describes the object more appropriately. (For an extensive discussion of uses of the term "transnational" in the law, see G-P Calliess, "Transnationales Verbrauchervertragsrecht", 68 RablesZ (2004) 244).

Cross border contracts have been predominantly made by traders, and for this reason a great number of rules of commercial contract law are in existence already. The 1980 Vienna Sales Convention (CISG) is only one example. This phenomenon is not limited to the European Union, and applies globally. The legal problems and limitations associated with it are also global and not specific to the European Union, and hence may not as such justify an EU competence to legislate. The reference of the EU Commission to the American Uniform Commercial Code and the Uniform Law Commission in the Green Paper, Opinion 3 (a) and note 23 therein [which hopefully with hindsight does not suggest to liken the draft CESL to the UCC], cannot justify legislative competence of the EU in the area of contract law generally. As long as the EU is not a state and legislative competence is derived from the Treaties, such comprehensive legislation as well as the establishment of a Law Commission comparable to the US Uniform Law Commission may exceed this scope. There is no obstacle, however, to the establishment of a European Law Commission and the drafting of comprehensive proposals outside the EU - although this would presuppose an openness on the part of private international law doctrine that is currently not there.

The problems arise from private international law so that much of the tailor-made transnational law does not find its way into the official jurisprudence and case law because it cannot be chosen as the "proper law of the contract", the lex contractus, the governing law of the contract to the exclusion of national law. Other problems resulting from this lack of practice remain in the area of private international law interpretation techniques. The new proposal does not solve this problem as will be explained below, even though it contains some excellent suggestions how to deal with transnational contract law (see Recital 29 of the Preamble and Art 4 of Annex I, and see 3(ii) below.

The reason for the existence of specific commercial contract law is equally not specific to the European Union but to the nature of cross border trade generally: international trade needs to cover specific risks and difficulties in its contracts which will not arise in the same way in domestic contracts. Examples are force majeure clauses and specific inspection and delivery rules. (Compare for more detail on this subject M Heidemann, "Does International Trade Need a Doctrine of Transnational Law? Some Thoughts At the Launch of a European Contract Law $\backslash 2$ (Springer Briefs in Law, Springer, Berlin, Heidelberg, New York 2012).

At the same time, the national legislator is naturally confined to its national territorial boundaries so that legislating for transnational contracts is not possible. This may be why they disappear easily from the legislature's "radar" and conscious awareness.

The aspects which would make this matter a suitable subject for EU legislation are the following:

- To the extent that the EU is based on and promotes the internal market, cross border transactions increase. The national legislature still remains in the same confined position.

- To the extent that the EU has created the internal market by removing trade barriers and establishing EU citizenship cross border transactions have expanded from trade and commerce into the sphere of consumers and private transactions. This certainly ought to be of enough concern to justify EU legislation in this area. While the concept of "private" benefit of the achievements of the EU Treaty freedoms has always been subdued (eg by the sparse instances of procedural rights for the individual and the initial confinement of free movement of persons to work related migration) and channelled indirectly through the concept of market benefit and the benefit of the internal market as such, the Union has nevertheless created a vast amount of law directed at consumers.

This could be read as both an argument against and in favour of the new contract law proposal. While the consumer may have been seen solely as a commercial factor within the internal market by the EU organs (due to the need to observe the scope of the Treaties) so far any uniform EU-wide contract law has a more free standing nature and is not closely bound to commercial developments as it will have to be based on the general understanding of contract law by the citizens using this law. 
So, while the EU legislature is bound by the scope of the EU Treaties, the general contract law goes further than that. This inherent conflict needs to be eliminated in order to create a successful proposal in this area. If this is not possible, CESL may be a more suitable project for an international Convention which can be signed and ratified by all MS regardless of Treaty powers. (This suggestion was already made at the outset of the current legislative proposal, cf M W Hesselijnk, “The European Commission's Action Plan: towards a more coherent European Contract Law?”, European Review of Private Law (2004) 397, 412; and $\mathrm{W}$ van Gerven, "Coherence of Community and national laws; is there a legal basis for a European Civil Code?", ERPL (1997) 465).

It has to be recognised that uniformisation of law within the EU is not an accepted end in itself under the current Treaties as the above-mentioned legal opinions correctly express. However, the fact that as a result of the creation of the internal market consumers increasingly face similar problems to international traders arising from the fact that contracts may be transnational in nature feeds into the plan at the start of the Common European Sales Law project: the consolidation of the EU consumer acquis.

It is clear that the current proposal focuses mainly on consumer contracts despite the inclusion of contracts between traders. It is also clear that despite being called a sales law the proposal includes issues of general contract law and therefore exceeds its published scope. It is further clear that the current proposal envisages mainly problems of internet sales ("e-commerce") and distance ("offpremises") sales. It is therefore not far-fetched to propose that the optional Common European Sales Law should be a mandatory Common European Consumer Law. Limiting the scope of such law to transnational contracts would have been a natural addition not only to the existing consumer law already implemented but also to existing commercial contract law which does not necessarily need to be included into such a proposal. (see Heidemann (2012) and see also Hans-W Micklitz and N Reich, The Commission Proposal for a "Regulation on a Common European Sales Law (CESL)" - Too Broad or Not Broad Enough?, EUI Working Paper LAW 2012/04 (commissioned by the Austrian Ministry of Consumer Affairs); available at http://cadmus. eui.eu/bitstream/handle/1814/20485/LAW_2012 04_Mic klitz_Reich.pdf? sequence $=3$ [10 April 2012]; and further The Law Commission and Scottish Law Commission, An Optional Common European Sales Law: Advantages and Problems. Advice to the UK Government (The Law Commission, Scottish Law Commission, 2011), p 39).

The defining characteristics of transnational consumer law are the typical factual problems arising out of the cross border situation such as bridging geographical distance, language, different legal understanding and background, but also importantly out of modern technological advance and business organisation which leaves the consumer to handle technology in order to purchase, pay and deliver or receive goods as well as having to deal with a potentially overbearing anonymous contract partner (see below 4(i)). These typically lead to the difficulties described by consumer groups and the above - mentioned Dutch study.

For these problems solutions can well be made at EU level because it is the supranational legislator of choice from where previous law has emanated and which - other than commercial contract law - is not present to the same extent in the wider world beyond the EU (the "natural legislator" - see J Dalhuisen, "The Modern Lex Mercatoria and its Dynamism”, Blog on Opinio Iuris, 3 April 2012, http://opiniojuris.org/2012/04/03/the-modern-lexmercatoria-and-its-dynamism/ [9 April 2012]).

The instrument of a regulation is also the instrument of choice given that the transnational nature of the transactions prevents the national legislators from legislating effectively in this area (see Explanatory Memorandum, p 10, (s 3) confirming conformity with the principle of proportionality).

Leaving such an instrument optional, however, is not promising as the protective nature of the contract rules therein may not appeal to the traders who, under the current proposal, and according to correct observations of consumer groups as conveyed by parliaments, will be the ones to offer those terms and not the consumer; of Reasoned Opinion of the UK House of Commons 2011, No 31, and see also recital 22 of the Preamble.

\section{PRIVATE INTERNATIONAL LAW}

The proposal aims to avoid problems of private international law and any changes in the existing catalogue of conflict rules. Earlier considerations to change the wording of Article 6 of the Rome I Regulation published in the Green Paper (see above 2, Option 4) have not manifested in this draft proposal.

\section{(i) National or transnational law?}

The current proposal emphasises that the CESL is to be regarded as national law, a separate regime alongside domestic contract law. These intentions are set out in the Explanatory Memorandum and in the Preamble (Explanatory Memorandum p 6, Preamble, recital 9), but they are not reflected in the Regulation or the Sales Law itself. It is therefore questionable if this result is supported by the existing law.

Recital 10 suggests a choice of law procedure that may sound simple but is far more complex upon a closer look. It obviously seeks to preserve the choices made by the Rome I Regulation (Reg (EC) 593/2008) and allow only the choice of the law of a state, not transnational law, regardless of whether this is formal or non-state law. It therefore presupposes a choice of law which then determines the CESL to apply to a contract as part of such domestic contract law. One would then technically not 
choose CESL as the governing law but "MS law CESL" or "the law of the state of $\mathrm{x}$ and its CESL" or "the CESL of state $x$ ". Parties to a contract should be made aware of this, and of the fact that there are still many issues remaining which may have to be resolved according to national laws, and that the choice of this national law should be made by them or be subject to the Rome I Regulation (Preamble, recital 27 and see below). It is my submission therefore that Recital 10 of the Preamble simply does not work and makes no sense.

The second aspect that makes the CESL a peculiar item in terms of private international law is that it is of course a transnational law in that it wants to provide a uniform source of law applicable to cross border contracts. This source of law has emanated from the EU legislator and not from the national Parliaments as is the case with national law. It is therefore debatable whether CESL and the Regulation can be regarded as national law even though the Regulation is of course directly applicable (in support of this view see the Austrian Reasoned Opinion issued by the Federal Council, accessible at http://www.ipex.eu/IPEXLWEB/scrutiny/COD20110284/atbun.do [28 April 2012]).

The German doctrine surrounding CISG shows how difficult the answer to the question is. CISG, even though implemented into German law by way of the EGBG the PIL act, is meant to remain subject to mandatory rules of German law and hence seems to be referred to as a legal order outside the domestic. Leible called the legal nature of EU rules "ambivalent" in his talk at the EP hearing on 1 March 2012 but dismissed the argument of the Austrian Federal Council that the choice of law stipulation might not have the desired effect; cf Stefan Leible " The proposal for a Common European Sales Law - how should it function within the existing legal framework" (para 2), accessible at http://www.europarl.europa.eu/document/activities/cont/2 $\underline{\text { 01203/20120307ATT40127/20120307ATT40127EN.pdf }}$ [28 April 2012].

The EU legislator seems to have a similar perception of CESL when it is suggested that CESL may be chosen to govern the contracts even between parties resident in an EU Member State and parties from third countries (Preamble, recital 14). CESL thereby displays a certain oscillating legal nature.

Article 11 of the Regulation requires the "exclusive application in relation to national law." Recital 27 of the Preamble sets out where the limits of CESL are and these items form the interface with national law and the application process then reverts back to the standard mechanism of establishing a national law to govern the contract and taking solutions from there. This leads to the next point, the interpretation rules for CESL (see 3(ii) below).

The peculiarity of this model becomes even clearer when looking at recital 14 of the Preamble where the mechanism for the choice of CESL in contracts between an EU trader and a consumer from a third party state is sketched: the choice of CESL is meant to be the choice of a foreign law for that "third party consumer" and subject to general choice of law rules. Hence the problem of choosing this foreign law is subject to exactly the same problems as it has always been, namely that the foreign law is largely unknown to the "third party" consumer, that his or her home state mandatory consumer law will prevail over CESL, that he or she cannot really influence this choice, and so forth. A foreign law can also not be chosen in parts so that it becomes clear that CESL is lacking an important quality when made to have an existence exclusively as an integral part of national contract laws and confined to the EU area.

Transnational trade needs a more universal approach which cannot be taken by the EU legislature because of the restrictions of the EU Treaties (cf 2(iii) above).

\section{(ii) Interpretation technique}

Recital 29 of the Preamble supported by Article 4 of Annex I (CESL) describes the interpretation technique for CESL. This is a summary of the most important points to note about interpretation of any international and transnational law, the so-called autonomous interpretation method. The EU legislator cannot be applauded enough for including this section into the proposal. This technique is a vital ingredient in the creation of a doctrine of transnational law. This recital alone would merit a regulation. Without it no tailor-made transnational law can be applied effectively and fulfill its objective, which is providing suitable law for cross border transactions. Recital 29 is of paramount importance, especially in connection with the above-mentioned recital 27 which enumerates those questions of law that are excluded from CESL. Experience shows that users of transnational law are all too tempted on reaching the interface with national law to understand the clauses to be a conflict rule and happily revert back to their own domestic law, as this is what they understand. What is needed, though, to develop a full regime of transnational contract law is an understanding of the transnational or cross border nature of the transaction in dispute. Article 7 CISG and many other international conventions contain the respective clause:

\section{[Vienna Convention on the International Sale of Goods 1980] \\ Article 7 \\ (1) In the interpretation of this Convention, regard is to be had to its international character and to the need to promote uniformity in its application and the observance of good faith in international trade.}

(2) Questions concerning matters governed by this Convention which are not expressly settled in it are to be settled in conformity with the general principles on which it is based or, in the absence of such principles, in conformity with the law applicable by virtue of the rules of private international law.

To match the provisions made in recital 29, Article11 of the Regulation provides for the exclusive application of 
CESL to the exclusion of national contract laws. Recital 29 ought to be included in Article 11 of the Regulation. Article 8(3) of the Regulation provides that CESL cannot be chosen in parts but only as a whole. These principles ought to apply to any set of transnational contract laws.

Another obvious aspect of interpretation technique is of course jurisprudence and case law. Article 14 of the Regulation prescribes the creation of a data base and reporting duties for the Member States regarding "final judgments." However, there is no explanation of the reasons and purpose for this. The model for this database is obviously CISG and the informal database at Pace Law School Institute of International Commercial Law and at the Unidroit Institute in Rome (UNILEX), where users are invited to form a "jurisconsultorium" in order to form a standard of interpreting CISG or the UNIDROIT Principles of International Commercial Contracts respectively (see C Baasch Andersen, The Uniformity of the CISG and its Jurisconsultorium, (Kluwer Law International, Alphen aan den Rijn 2007). A doctrine of binding international precedent does not exist to this day, however. It is therefore questionable what the purpose and legal basis for the installation of such a database is. The closest one can get to international precedent is the doctrine of Entscheidungsharmonie, which postulates reference to other decisions in courts of different countries about a particular question of international law so that a certain harmonious accord can be achieved even in the absence of a dedicated higher authority for a particular question of law.

In the case of EU law, however, this authority will be the courts of the EU. These in turn may face such an excessive workload when consulted about questions of contract law under CESL that it is highly doubtful if justice could be delivered in this way. The courts have also so far essentially adjudicated about the scope of the Treaties. Regarding CESL, they may for the first time be confronted with contract law cases and required to judge about private law directly within the existing structure of limited procedure, ie preliminary rulings and complaints about breach of EU law by public bodies and individuals in certain limited cases under the revised procedures. It is not at all straightforward to assume that this provides a sufficient infrastructure to manage contract law on this EU-wide scale. No explicit plans to use the possibility to install a specialised branch of the courts exist to date.

\section{(iii) Relation to CISG}

Recital 25 of the Preamble states that a choice of CESL excludes the application of CISG. The planned database experience with the respective databases established for the use of CISG and the use of UNIDROIT Principles is therefore also dismissed, despite drawing on this model with the suggestion. It is unclear what purpose is pursued by this policy. One purpose may be the reinforcement of the intended scope of CESL: it can be chosen in business to consumer ( b2c) contracts but also for contracts between traders if one trader is a small or medium-sized enterprise (SME - see Art 7 of the Regulation). States can provide for CESL to be agreed to be the governing law for contracts between large traders. CISG is of course the legal regime of choice for commercial contracts, and equally part of domestic law in those countries who have ratified the Convention. It was probably envisaged that clashes would arise from encountering parallel regimes in this way upon a choice of CESL.

The author does not share this concern. CISG and CESL would only overlap in scope in some instances where CESL is eligible as the governing law. A priority clause would clarify the order of application between the two regimes, but may not even be necessary as "domestic law" is already taking second place after CESL when it is selected. CISG as part of domestic law - where this conception is adopted - will share this role. This way, the databases and potential analogies could still be utilised without creating an additional doctrinal obstacle. The exclusion clause is therefore unnecessary.

The Explanatory Memorandum refers on page 5 (s 1) to CISG and emphasises that "there is no mechanism which could ensure its uniform interpretation." While this is technically true, many years of experience with CISG have established an international body of case law that may not have official endorsement but seems to yield certain results which have made its way into the CESL. Article 121 for instance seems to incorporate (German) case law on Article 38 and 39 CISG and provide some sort of restatement of findings made in this area (for instance the interpretation of the expression "reasonable time" as meaning 14 days by default, see below 4(ii). Courts have predominantly found the notice period "too long" or "reasonable" rather than settling on a fixed time span.

Another question is whether it is suitable to replace CISG by CESL and insist on the inclusion of commercial contracts, ie business to business (b2b) contracts into CESL. I have commented in depth on this elsewhere (cf Heidemann (2012)).

In my view it would be preferable to take the scope of CISG as a starting point and create CESL as complementary law to CISG governing consumer sales contracts providing the complementary scope provision based on Article 1 and 2 CISG:

[Vienna Convention on the International Sale of Goods 1980]

Article 1

(3) Neither the nationality of the parties nor the civil or commercial character of the parties or of the contract is to be taken into consideration in determining the application of this Convention.

Article 2

This Convention does not apply to sales:

(a) of goods bought for personal, family or household use, unless the seller, at any time before or at the conclusion of the contract, neither knew nor ought to have known that the goods were bought for any such use;... 
The problems of gaps as mentioned in the Explanatory Memorandum can only be resolved by recourse to either other suitable rules of transnational law or domestic law by way of an evolving and improved doctrine of private international law (see for a clear description of the method of handling international law sources J Dalhuisen, "The Operation of the Modern Lex Mercatoria: The Hierarchy of Norms," guest blog on Opinio Iuris, 3 April 2012, http://opiniojuris.org/2012/04/03/theoperation-of-the-modern-lex-mercatoria-the-hierarchy-ofnorms/ [8 April 2012].

\section{SUBSTANTIVE LAW - REGULATION, ANNEX 1}

In this section I comment on a selection of Articles which display weaknesses or possibly even errors, and also suggest how to offer an improved solution.

\section{(i) Regulation}

\section{Article 4}

Article 4 is one of the scope provisions and establishes when a contract is a cross-border contract and eligible to be governed by CESL. It stipulates that certain criteria need to be allocated to different countries and at least one those an EU MS.

These criteria are different depending on whether the party is a trader or a consumer. For traders it is required that they have their "habitual residence" in different countries (Art 4 (2)). For consumers, however, it is sufficient that their address is in a country other than that of the habitual residence of the trader ("address" meaning billing address, delivery address or just "the address indicated by the consumer", Art 4(3)(a)). This is striking.

First of all, the criterion of habitual residence is not without its difficulties. In the case of a "trader," problems of localisation caused by business organisation will arise. . Consequently, Article 4(4) and (5) explain the "habitual residence" of the trader in more detail and qualify this criterion in a much more meaningful way (ie introducing the central administration, principal place of business, branch, agency, "any establishment". Compare also in connection with this problem The Law Commission and Scottish Law Commission, An Optional Common European Sales Law: Advantages and Problems. Advice to the UK Government (The Law Commission, Scottish Law Commission, 2011), pp 13-19 and 35-39).

Those additional criteria are more tangible and easier to understand by the average consumer. They ought therefore to be the ones to be used to give the consumer guidelines how he or she can recognise and double check whether his or her contract qualifies for the application of CESL. The criterion of habitual residence - apart from being ideally related to natural persons - is of course modelled on the Rome I Regulation, but is by no means helpful or necessary in this context. Article
Regarding the address of the consumer, this obviously puts the trader in an awkward position. Addresses are easily given and if this is a criterion that allows the application of CESL even in cases where the address might turn out to be wrong and the habitual residence of the consumer contract partner later turns out to be in the same MS as the trader's branch. Only then can the trader truly rely on this provision, which leaves a lot of uncertainty as to the valid choice of CESL for both parties, but most of all for the trader.

Again, Articles 1 and 2 CISG, the scope provisions of CISG, provide an excellent model for the solution of this problem, including potential errors about the parties' localisation. "Place of business" is an expression which summarises branches, agencies and central administrations more clearly to a legally untrained consumer than the expression "habitual residence" which is obviously intended to maintain coherence with the Rome I Regulation for better or worse.

\section{Articles 5, 6, 7, 10 and 13}

Articles 5 describes the type of contract CESL can be used for, ie sales contracts (a) and related service contracts (c). Contracts for the supply of digital content (b) are also expressly mentioned. Article 6 then expressly excludes certain contract types but other scope articles use positive language describing the scope of application and eligible parties.

Again, taking recourse to Articles 1 and 2 CISG could be worthwhile here. CISG provides a very elegant way of creating a scope which can be integrated into the existing dichotomy of merchant and non-merchant contracts (Art 1 (3) CISG) as it is still maintained in most European civil laws.

[Vienna Convention on the International Sale of Goods 1980]

Article 1

(1) This Convention applies to contracts of sale of goods between parties whose places of business are in different States:

(a) when the States are Contracting States; or

(b) when the rules of private international law lead to the application of the law of a Contracting State.

(2) The fact that the parties have their places of business in different States is to be disregarded whenever this fact does not appear either from the contract or from any dealings between, or from information disclosed by, the parties at any time before or at the conclusion of the contract.

(3) Neither the nationality of the parties nor the civil or commercial character of the parties or of the contract is to be taken into consideration in determining the application of this Convention.

Article 2

This Convention does not apply to sales:

(a) of goods bought for personal, family or household use, unless the seller, at any time before or at the conclusion of the contract, neither knew nor ought to have known that the goods were bought for any such use; ... 
CISG describes consumer contracts in Article 2 (a). It picks up on the so-called objective approach to denominating commercial, or in this case, private contracts. It is to be considered whether this is not a more suitable approach rather than embarking on a characterisation of the parties to the contract as consumers or traders. The "personal scope" of the proposal seems to serve as an important factor in meeting the legitimisation criteria under the EU Treaties (see Explanatory Memorandum, p 10 (s 3.)) A description of the purpose of the contract as in Article 2 CISG instead catches the most characteristic difference between a private and a commercial contract. It is the use that the parties want to make of the purchased goods or digital content. This intention and attitude towards the object of the contract distinguishes the trader from the consumer. The consumer wants to keep and use the goods whereas the trader wants to pass them on, he or she receives them with the sole purpose of reselling. This is the reason why contract law needs to reconcile the interests of these two parties, rather than a difference in personal characteristics in the consumer or trader

A focus on the contract and its purpose may allow a more neutral attitude of the legislator and the provision of more appropriate solutions. As explained in 2(iii) above, the problem to be solved may not have been sufficiently defined and analysed prior to the creation of this tailor made law.

If it is predominantly the consumer who is at the heart of this measure then surely contracts among consumers (consumer to consumer - $\mathrm{c} 2 \mathrm{c}$ ), ought to have been considered here, too. Ebay for instance provides a platform that could be used by consumers across Europe if the question of the applicable law was easier to establish. Ebay, like a giant car boot sale, is a reality for consumers all over Europe who are currently making use of modern technologies available to them, but are usually still confined to their own country.

The characteristics of modern cross border trade are determined by the presence of electronic means of communication and payment and e-commerce, as well as by the highly professionalised production methods and business organisation leading to mass retail and with it a highly anonymous appearance of the trader in the face of the consumer. These issues require both a suitable legal basis for substantive contract law and choice of law as well as a suitable infrastructure to assist the consumer in order to match the organisation levels of the businesses he or she is dealing with. The subject matter was at the heart of the academic debate about unfair contract terms legislation when that began (see the essay by Professor Hans Merz ,"Massenvertrag und allgemeine Geschäftsbedingungen" in Law Faculty of the University of Fribourg (ed), Festgabe für Wilhelm Schönenberger: zum 70. Geburtstag am 21, September 1968 (Universitätsverlag, Freiburg (Schweiz) 1968)).
A modern instrument for European cross border trade should meet the whole range of facilities available to the consumer in the wake of the removal of trade barriers in the form of tariffs and non-tariff barriers under the four freedoms of the EU internal market. This ranges from one-off transactions between private parties to mass retail conducted by international concerns. It is therefore advisable to concentrate on the provision of consumer sales law to counteract distortions in the balance within the contractual relationship between consumers and businesses which are doubtlessly present and have been identified by research over the past decades.

Returning to the original project of consolidating the consumer acquis and providing both contract law and accompanying infrastructure to support consumer sales would therefore be a natural way forward. The provision of the forms in Annex I and II of the proposed instrument are an important step into this direction.

The purpose of Articles 7 and 13 CESL is not immediately clear. Traders are supposed to be able to elect CESL to govern their contract even if no consumer is involved, but only if one of them is an "SME" unless states have extended the scope according to Article 13. The question is why would they want to do so? It is a known factor and experience that small businesses have certain disadvantages in relation to large businesses. This can include the inability to influence the terms of business due to weak negotiating power as well as a lack of available resources in order to establish the details of a foreign law if forced to accept a respective choice of law clause. It is not clear, though in which way traders will have an advantage from the choice of CESL. Unfair contract terms legislation will be available to them under domestic European laws. The specific advantages consumers have under CESL are not available to them as traders. The specific b2b clauses of CESL are identical in CISG and the UNIDROIT Principles supported by case law. There is therefore no obvious reason why CESL would be an advantage over the choice of domestic law including CISG or indeed any other tailor made transnational commercial contract law.

The definition of SMEs displays another difficulty introduced by the creators of CESL. This definition is based upon Commission Recommendation 2003/361 from 2003 and identical to those used in national taxation laws to establish the thresholds for the application of stages of corporation tax or reporting duties. It is regrettable to see an intrusion of the spirit of regulatory and public law into a genuinely private law sector. It puts another question mark behind the EU as the "natural legislator" for this project.

The same goes for Article 10, which requires the MS to establish "penalties" for the breach of information and other duties under CESL, a genuinely alien remedy in contract law. (breaches of Arts 8 and 9 of the Regulation, complete with standard wording for the penalty to be 
"effective, proportionate and dissuasive." Contract law is essentially concerned with the enforceability of claims rather than with behavioural rules as such. For this reason sanctions for the breach of such rules are not needed, the breach will be sanctioned via the lack of enforceability. (Apparently this is not clear any more in modern law reform, as the new German concept of "breach of duty" in the BGB of 2001 shows: cf M Heidemann, "International Commercial Harmonisation and National Resistance The Development and Reform of Transnational Commercial Law and its Application within National Legal Culture" in M Andenas and C Baasch Andersen (eds), Theory and Practice of Harmonisation (Edward Elgar Publishing, 2011)).

Remedies like fixed penalties (independent of liquidated damages), strict liability and last but not least the astreinte, have therefore found their way into international contract law only after fierce discussion, and some are still meeting firm resistance from those users whose countries do not traditionally recognise them.

The legislature does not explain what legal nature such penalties under Article 10 ought to have, and which elements of breach they are supposed to sanction. Resulting differences in the national laws will add to the list of excluded matters listed in recital 27 of the Preamble.

\section{(ii) Annex 1 (the Sales Law)}

In this section a small selection of individual rules is highlighted in chronological order to show weaknesses in the drafting which could be easily rectified.

It is not clear what aims are pursued through the choice of language and style. While cross referencing is usually clear and straightforward, as is the revised method of counting the Articles (compared to previous drafts such as the CFR and PECL), the language is apparently sometimes oversimplified, as it is sometimes inconsistent or incorrect. It is not clear if it is supposed to be simple at the expense of correctness and technical coherence in accordance with existing law.

\section{Articles 119-122}

One cannot help thinking that these articles dealing with inspection duties among traders have not only been drafted after the model of CISG and UNIDROIT Principles but that some of the case law on those rules has been included into these articles in the manner of a restatement. The stipulation of a "reasonable time" for inspection in CISG has now been specified to be two weeks. Article 119 maintains the "reasonable time" requirement.

It is not clear why it was thought that drawing on the experience with domestic jurisprudence and doctrine involving CISG is alright, but otherwise CISG needs to be excluded from use alongside CESL. Any further evolution of those provisions, which have obviously been taken from these earlier sets of rules, is thereby prevented for CESL and an entirely fresh start will have to be made. Ignoring previous work on uniform law is therefore unhelpful.

\section{Article 129}

“(a) doing all the acts...": is this a necessary choice of words?

\section{Article 131}

Paragraph (4) is unclear. It is one example where an effort was made to draft in clear simple terms for easy understanding by the user. The last paragraph however will not be easy to apply by a legally untrained user. Double negation is not the terminology of choice.

\section{Article 132}

Is it necessary to use the expression "recover" when it concerns the first instance of being entitled to the price? In Articles 120(2) and (3) where the word recover is appropriate, it denotes a loss or overpayment to be "recovered."

\section{SUBSTANTIVE LAW - ANNEX II}

Annex II consists of the Standard Information Notice. Two points are of concern.

\section{(i) Validity of choice of law agreement}

The third paragraph (p114, para 3) stipulates that "the contract will only be valid after you have received this notice and confirmed your consent." It is not clear that this wording only relates to the agreement to make CESL the applicable law. It seems to refer to the sales contract as such. If this wording is not changed it will have the effect that the sales contract is only valid after the consumer has received notice of CESL inclusion.

Apparently it is intended that this notice necessarily needs to be a hard copy which will delay contracts made by electronic means. Is this the intended legal consequence? If so, is it necessary? It will cause delays in the cases mentioned therein (contracts made via SMS or telephone). This is a departure from general contract law where the applicable law does not affect the validity of a contract. Alternatively, if this is a misleading wording or clerical error then it must be redrafted. Care should be taken that consumer contract law does not drift off into the area of guardianship.

\section{(ii) Damages provision for breach of information notice}

"Your rights before signing the contract": last sentence, "you are entitled to damages." Is this correct? Does one not have to prove a loss or harm? Is this meant to be strict liability or a fixed penalty? Is this referring to Article 10 CESL?

I do not believe the current wording is appropriate, it is misleading and ought to be revised. 


\section{CONCLUSION}

The proposal on the optional Common European Sales Law offers excellent new instruments to support cross border trade. The inclusion of forms to help the trader and the consumer to observe basic requirements of current EU consumer and private international law are progressive and useful. In order to observe the limits of EU competences, the proposal ought to be limited to consumer contracts. It should equally include consumer to consumer contracts. In addition to providing contract law rules it should extend and improve a complementary infrastructure for consumers to match existing high levels of business organisation on the part of businesses currently trading across borders in the form of procedural rules and consumer agencies, representations and organisations. This cross border consumer contract law should be mandatory not optional.

The scope of the CESL could be successfully drafted after the model of CISG, providing a complementary instrument to this existing body of transnational commercial contract law. The transnational legal nature of CESL must be recognised and supported by choice of law rules and a firm recourse to the autonomous interpretation technique in recital 29 of the Preamble and Article 4 CESL (Annex I). Additional research work should be done to define the requirements of international consumer contracts and establish the needs to be included into CESL based on the purpose and requirements of the contracts rather than the parties, following the traditional objective approach to existing law merchant. This will also be in the interest of preserving the integrity of existing national private law and thereby satisfy requirements under the EU Treaties.

Private autonomy should be strictly observed as the basis for legislation. Recourse to public policy instruments such as penalties for behavioural rules modelled after breaches of Treaty law and providing stifling definitions of contractual parties such as SMEs should be avoided. This is in the interest of preserving contract law as a domaine of private law.

Finally, adjudication of case law arising out of CESL must receive special attention and be accompanied by guarantees of an appropriate jurisdictional infrastructure and procedural rules. Arguments challenging the competence of the EU under Article 114 TFEU in this area should be taken seriously, especially in view of the flawed consultation process.

\section{Dr Maren Heidemann}

Assessor Iuris (Germany), LLM, PhD (Nottingham), Visiting Fellow, Institute of Advanced Legal Studies, University of London. This article is based on a talk given at the IALS on March 29, 2012

\section{Articles for Amicus Curiae}

Amicus Curiae welcomes contributions, which should be accompanied by the name and contact details of the author. The journal publishes articles on a wide variety of issues, ranging from short pieces of 700-1,200 words and longer articles of 4,000 words of so (the upper limit can be extended where appropriate). Articles should be written in an informal style and without footnotes.

Anyone interested in submitting a piece should email Julian Harris (julian.harris@sas.ac.uk). 